Key messages

- During war, mines and fragmenting munitions (mortars, bombs, and shells) are more likely than bullets to injure civilians

- Civilians in a city under siege are particularly at risk of being injured by weapons whose users are not able to see the victim

- The inherent nature of weapons may be a factor in determining whether civilians are killed or injured

- There is a need for greater respect for the Fourth Geneva Convention and for greater controls on weapons being transferred to untrained and undisciplined forces

that they kissed the rockets, shells, and mortars before they were loaded so that God would decide whether they hit the enemy.

Both increased destructive force and increased distance between user and victim are features of military efficiency of a weapon system. This study supports the proposal of a fundamental principle: with greater military efficiency of weapons comes an inherent and increased potential for injuring civilians. ${ }^{12}$ The data from Kabul are pertinent to the global trend of urbanisation of societies and show how the potential of any weapon to injure civilians is exaggerated in urban settings.

Weapons, law, and preventive medicine

The process of making or promoting policy and law entails analysing data which clarify the nature of the problem that the policy or law is trying to avoid. International humanitarian law is no exception. These data show that the number of civilian injuries is related not only to whether weapons are in the hands of untrained and undisciplined users but also to the type of weapon in those hands. This argues for a greater need to control the transfer of weapons of increasing military effi- ciency and warrants urgent and serious examination of states' obligations under international humanitarian law in relation to arms transfer. Such an examination should naturally follow the precedent set by the drawing up of a treaty banning the production, stockpiling, transfer, and use of antipersonnel mines. The medical profession has a responsibility to examine the global weapon problem as a health issue ${ }^{12}$; this is a form of preventive medicine.

Contributors: HOS first found variation in age and sex of patients according to cause of injury on examining the ICRC surgical database. RMC had the core idea that the weapon type may lend itself to indiscriminate use, formally re-examined the database, and wrote the paper. RMC is guarantor for the study.

Funding: No additional funding.

Competing interests: None declared.

1 Sidel VW. The international arms trade and its impact on health. BMJ 1995;311:1677-80.

2 Coupland RM. The effects of weapons on health. Lancet 1996;347:450-1.

3 Bowyer GW. Management of small fragment wounds in modern warfare: a return to Hunterian principles? Ann R Coll Surg 1997;79:175-82.

4 Sellier KG, Kneubuehl BP. Wound ballistics. Amsterdam: Elsevier, 1994.

5 Coupland RM, Korver A. Injuries from antipersonnel mines: the experience of the International Committee of the Red Cross. BMJ 1991;303:1509-12.

6 Coupland RM. Hand grenade injuries among civilians. JAMA 1993;270:624-6.

7 Andersson N, Palha da Sousa C, Paredes S. Social cost of land mines in four countries: Afghanistan, Bosnia, Cambodia and Mozambique. BMJ 1995;311:718-21.

8 Ascherio A, Biellik R, Epstein A, Snetro G, Gloyd S, Ayotte B, et al. Deaths and injuries caused by landmines in Mozambique. Lancet 1995;346:721-4.

9 Jeffrey S. Anti-personnel mines: who are the victims? J Accid Emerg Med 1996:13:343-6.

10 Garfield RM, Neugut AI. Epidemiological analysis of warfare: a historical analysis. JAMA 1991;226:688-92.

11 Prokosch E. The technology of killing. London: Zed Books, 1995

12 International Committee of the Red Cross. The medical profession and the effects of weapons: the symposium. Geneva: ICRC, 1996.

13 Coupland RM. Epidemiological approach to the surgical management of the casualties of war. BMJ 1994;308:1693-7.

14 Grossman D. On killing: the psychological cost of learning to kill in war and society. Boston, MA: Little, Brown, 1995.

(Accepted 29 September 1998)

\title{
Circumstances around weapon injury in Cambodia after departure of a peacekeeping force: prospective cohort study
}

\author{
David R Meddings, Stephanie M O'Connor
}

\section{Editorial by Smith \\ Unit of the Chief Medical Officer, International \\ Committee of the Red Cross, \\ 19 avenue de la Paix, 1202 Geneva, Switzerland \\ David R Meddings epidemiologist}

continued over

BMJ 1999;319:412-5

\begin{abstract}
Objective To examine the circumstances surrounding weapon injury and combatant status of those injured by weapons.

Design Prospective cohort study.

Setting Northwestern Cambodia after departure of United Nations peacekeeping force.

Subjects 863 people admitted to hospital for weapon injuries over 12 months.

Main outcome measures Annual incidence of weapon injury by time period; proportions of injuries inflicted as a result of interfactional combat (combat injuries) and outside such combat (non-combat injuries) by combatant status and weapon type.

Results The annual incidence of weapon injuries was higher than the rate observed before the peacekeeping operation. $30 \%$ of weapon injuries occurred in contexts other than interfactional combat. Most commonly these were firearm injuries inflicted
\end{abstract}

intentionally on civilians. Civilians accounted for $71 \%$ of those with non-combat injuries, $42 \%$ of those with combat related injuries, and $51 \%$ of those with weapon injuries of either type.

Conclusions The incidence of weapon injuries remained high when the disarmament component of a peacekeeping operation achieved only limited success. Furthermore, injuries occurring outside the context of interfactional combat accounted for a substantial proportion of all weapon injuries, were experienced disproportionately by civilians, and were most likely to entail the intentional use of a firearm against a civilian.

\section{Introduction}

In many areas of the world military weapons are widely available. ${ }^{12}$ This has been argued to contribute to regional instability, increased civilian injuries, and violence that is not directly related to interfactional combat. ${ }^{34}$ 
Table 1 Characteristics of patients and type of injury. Values are numbers (percentages) unless stated otherwise

\begin{tabular}{lc} 
& Study population (n=863) \\
\hline Mean (SD) age (years) & $27.2(10.7)$ \\
\hline Male & $735(85.2)$ \\
\hline Civilians & $437(50.6)$ \\
\hline Injury type: & \\
\hline Mine & $317(37)$ \\
\hline Fragmenting munitions* & $262(30)$ \\
\hline Firearm & $252(29)$ \\
\hline Othert & $32(4)$ \\
\hline
\end{tabular}

*Includes bombs, shells, and grenades.

†Primarily knives or blunt weapons.

In 1990 the International Committee of the Red Cross began supporting Mongkol Borei hospital in Banteay Meanchey province in northwestern Cambodia. The hospital was the only facility in the region with the capacity to provide surgical care to people injured by weapons. The peace accords of 1991 led to the arrival of the United Nations Transitional Authority in Cambodia in March 1992. By October 1992 this international peacekeeping operation was supposed to have disarmed and demobilised 70\% of Cambodia's combatant factions. ${ }^{5}$ In November 1992 it announced that it could not meet this disarmament target because of non-compliance of some troops. Around 25-50\% of the troops are believed to have been disarmed. ${ }^{5}$

We prospectively examined combatant status and the circumstances surrounding injury for people with weapons injuries admitted to Mongkol Borei hospital during a 12 month period after the departure of the United Nations Transitional Authority in Cambodia.

\section{Patients and methods}

Between 1 March 1994, five months after the departure of the United Nations Transitional Authority in Cambodia, and 28 February 1995, all people admitted to Mongkol Borei hospital with weapon injuries received a structured interview eliciting demographic information, combatant status, and circumstances surrounding injury.

We categorised injuries as combat and non-combat on the basis of the context of injury and as occurring in civilians or military staff on the basis of combatant status. Combat injuries were defined as those sustained during interfactional combat or from stepping on a landmine. Injuries from all other contexts were classed as non-combat injuries, and subcategorised into those resulting from interpersonal violence or by accident. On the rare occasions that the classification of injury was ambiguous the category was assigned by one of us (SMO).

Incidence of weapon injury was calculated using admissions data from January 1991 to February 1995 and figures for the population of Banteay Meanchey obtained from the United Nations High Commissioner for Refugees. These rates were calculated for our study period and the periods preceding and during the mandate of the United Nations Transitional Authority in Cambodia.

\section{Results}

Table 1 shows the characteristics of the 863 people injured during our study. Mine injuries were most common, followed by injuries due to fragmenting munitions (mortars, bombs, or grenades) and firearms.

The figure shows the monthly admissions for weapon injury to Mongkol Borei hospital from January 1991 to February 1995. Injury rates varied seasonally. They were comparable before the arrival and after the departure of the United Nations Transitional Authority in Cambodia and reduced during its presence.

Table 2 shows mean annual and seasonally adjusted mean annual incidence of weapon injury for the study period and before and during the mandate of the United Nations Transitional Authority in Cambodia. Both rates were higher during the study period than before the arrival of the United Nations.

Table 3 presents our data disaggregated by injury context, combatant status, and weapon type. The box summarises the important points.

\section{Discussion}

Nearly one in three people sustained non-combat injuries. Moreover, intentional firearm injuries among civilians was by far the largest category of non-combat injury. This supports the contention that widespread weapon availability, in the context of a protracted conflict, is associated with a high rate of social violence.

\section{Limitations and potential biases}

Several limitations should be considered. We inferred that weapon availability was high without measuring it. However, a United Nations military survey in December 1991 reported that the Cambodian combatant factions possessed over 320000 weapons and over 80 million rounds of ammunition.

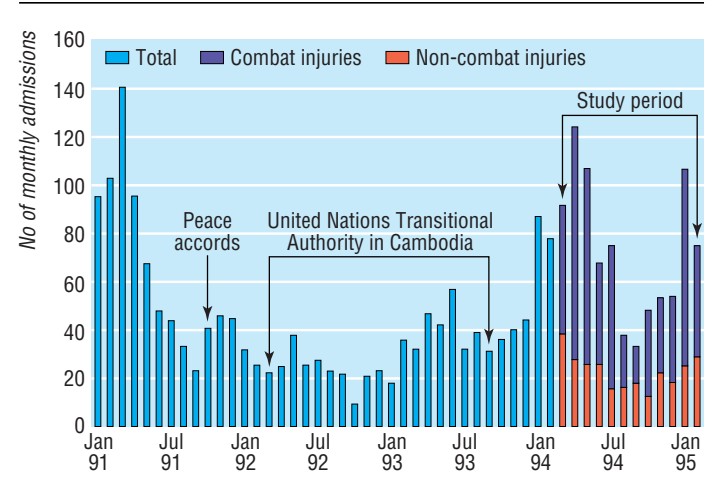

Monthly admissions for weapon injury to Mongkol Borei hospital, 1991-5

Table 2 Mean annual and seasonally adjusted mean annual incidence of weapon injury in Mongkol Borei hospital by period

\begin{tabular}{lccc} 
Period & $\begin{array}{c}\text { Mid-period } \\
\text { population }\end{array}$ & $\begin{array}{c}\text { Mean annual incidence } \\
\text { (injuries/100 000) }\end{array}$ & $\begin{array}{c}\text { Seasonally adjusted } \\
\text { mean annual } \\
\text { incidence* }\end{array}$ \\
$\begin{array}{c}\text { Before peacekeeping operation } \\
\text { (injuries/100 000) }\end{array}$ \\
\hline $\begin{array}{c}\text { (January 1991-February 1992) } \\
\text { During peacekeeping operation } \\
\text { (March 1992-August 1993) }\end{array}$ & 457177 & 158 & 147 \\
\hline $\begin{array}{l}\text { During study (March } \\
\text { 1994-February 1995) }\end{array}$ & 503176 & 69 & 163 \\
\hline
\end{tabular}

*Monthly weights were product of mean monthly admissions and reciprocal of month specific mean admissions. Division,

International

Committee of the

Red Cross,

19 avenue de la

Paix, 1202 Geneva

Stephanie M

O'Connor

head nurse

Correspondence to: Dr Meddings

dmeddings@icrc.org
Health Operations 
Table 3 Number of weapon injuries by context, combatant status, and weapon type

\begin{tabular}{|c|c|c|c|c|c|c|c|c|c|c|}
\hline \multirow[b]{3}{*}{ Weapon type } & \multicolumn{4}{|c|}{ Non-combat injuries } & \multicolumn{2}{|c|}{ Combat injuries } & \multirow[b]{3}{*}{$\begin{array}{l}\text { Total } \\
\text { civilian }\end{array}$} & \multirow[b]{3}{*}{$\begin{array}{c}\text { Total } \\
\text { military }\end{array}$} & \multirow{3}{*}{$\begin{array}{c}\text { Total } \\
\text { non-combat } \\
\text { injuries }\end{array}$} & \multirow[b]{3}{*}{$\begin{array}{c}\text { Overal } \\
\text { total }\end{array}$} \\
\hline & \multicolumn{2}{|c|}{ Civilian } & \multicolumn{2}{|c|}{ Military } & \multirow[b]{2}{*}{ Civilian } & \multirow[b]{2}{*}{ Military } & & & & \\
\hline & $\begin{array}{l}\text { Interpersonal } \\
\text { violence }\end{array}$ & Accident & $\begin{array}{l}\text { Interpersonal } \\
\text { violence }\end{array}$ & Accident & & & & & & \\
\hline Mine & 3 & 11 & 1 & 21 & 96 & 185 & 110 & 207 & $36(11)$ & 317 \\
\hline Fragmenting munitions $\dagger$ & 17 & 41 & 0 & 18 & 123 & 63 & 181 & 81 & $76(29)$ & 262 \\
\hline Firearm & 80 & 10 & 15 & 14 & 34 & 99 & 124 & 128 & $119(47)$ & 252 \\
\hline Other $\neq$ & 18 & 3 & 0 & 6 & 1 & 4 & 22 & 10 & $27(84)$ & 32 \\
\hline
\end{tabular}

*Values in parentheses are proportion of all weapon injuries attributable to non-combat injuries. †Includes bombs, shells, and grenades. $\ddagger$ Primarily knives or blunt weapons.

Important points from table 3

All injuries

- $59 \%$ of people injured were civilians or did not sustain their injuries as a

direct result of active fighting between armed factions, or both

- $51 \%$ of people injured were civilians

- $37 \%$ of all those injured were injured by mines

Non-combat injuries

- $30 \%$ of people sustained their injuries as a result of something other than active fighting between armed factions

- $71 \%$ of all people with non-combat injuries were civilians

- $67 \%$ of people with non-combat injuries from firearms were civilians

injured as a result of interpersonal violence

- $79 \%$ of non-combat injuries to military staff resulted from accidents

Combat injuries

- $46 \%$ of injuries related to combat were from mines

- $42 \%$ of all people with combat injuries were civilians

- $78 \%$ of civilians with combat injuries which required an act of

volition-that is, from all weapons except landmines-were injured by

fragmenting munitions (bombs, shells, and grenades)

- $60 \%$ of military staff with such injuries were injured by firearms and $38 \%$ by fragmenting munitions trained Cambodian colleagues who were debriefed daily, allowing ambiguities to be resolved while the patient was still in hospital. Finally, because classification criteria were unambiguous, few cases required designation of category.

\section{Mine injuries}

Our results add to other evidence of the extent of the problem of antipersonnel mines in Cambodia. ${ }^{78}$ Such data were instrumental in leading to the treaty on antipersonnel mines signed by 124 countries in Ottawa in December 1997.

\section{Civilian casualties}

The weapon type causing most civilian injuries was not mines but fragmenting munitions followed by firearms, weapons requiring an act of volition on the part of the user. Some authors argue that civilian casualties constitute a pressing humanitarian issue ${ }^{910}$ and advocate describing the epidemiology of the issue to address it with a public health approach. ${ }^{11}{ }^{12}$

The likelihood of civilian injury depends on the context in which a given injury was inflicted. These different contexts have very different implications for addressing civilian casualties. Fragmenting munitions accounted for nearly $80 \%$ of civilian casualties resulting from intentional weapon use in the context of combat. Some preventive strategies have been laid out in a recent review. ${ }^{11}$ Combatants also require better training in use of these weapons and in the rights of civilians to protection under international humanitarian law. A consideration in these efforts should be that combatants might feel less responsible for civilian casualties provided a distance separates them from the victims of their weapons. ${ }^{13} 14$

Preventing civilian casualties in non-combat contexts entails different considerations. Firearms accounted for most of these injuries, and almost $90 \%$ of civilian casualties inflicted with firearms occurred during interpersonal violence. Over a third of civilian casualties in non-combat contexts occurred by accident, and most of these concerned fragmenting munitions, namely, curious children pulling pins from hand grenades.

Despite different mechanisms of injury, we believe that these results provide support for the contention that reducing weapon availability is essential to curtailing social violence and providing conditions requisite for social development. ${ }^{24}$ Despite an estimated cost of \$1.5bn, the disarmament component of the mandate of the United Nations Transitional Authority in Cambodia was abandoned. ${ }^{5}$ Our findings reflect the human cost of this decision. It is a cost we believe
- Widespread availability of weapons can facilitate social violence 
should be considered in international policies concerned with arms availability and transfer.

Contributors: DRM conducted the analysis and interpretation of the data, discussed core ideas, and wrote the paper. SMO initiated and coordinated the collection of data, discussed core ideas and interpretation of the data, and participated in writing the paper. DRM is guarantor of the paper

Funding: No additional funding.

Competing interests: None declared.

1 Boutwell J, Klare MT, Reed LW, eds. Lethal commerce: the global trade in small arms and light weapons. Cambridge, MA: Committee on International Security Studies, American Academy of Arts and Sciences, 1995.

2 Williams P. Transnational organised crime and international security: a global assessment. In: Gamba V, ed. Society under siege: crime, violence and illegal weapons. Halfway House, South Africa: Institute for Security Studies, 1997:11-41.

3 Meddings DR. Weapons injuries during and after periods of conflict: retrospective analysis. BMJ 1997;315:1417-20.

4 Zawels EA, Stedman SJ, Daniel DCF, Cox D, Boulden J, Tanner F, et al. Managing arms in peace processes: the issues. Geneva: United Nations Institute for Disarmament Research, 1996.
5 Wang J. Aborted disarmament. In: Managing arms in peace processes: Cambodia. Geneva: United Nations Institute for Disarmament Research, 1996:32-82. (Disarmament and conflict resolution project.)

6 Coupland RM. Epidemiological approach to surgical management of the casualties of war. BMJ 1994:308:1693-7.

7 Asia Watch, Physicians for Human Rights. Land mines in Cambodia: the cowards'war. Boston: Asia Watch, Physicians For Human Rights, 1991.

8 Andersson N, da Sousa C, Paredes S. Social cost of land mines in four countries: Afghanistan, Bosnia, Cambodia, and Mozambique. BMJ 1995;311:718-21.

9 Cobey JC, Flanagin A, Foege WH. Effective humanitarian aid. Our only hope for intervention in civil war. JAMA 1993;270:632-4.

10 Comninellis N. War and health: a view of Africa. Tropical Doctor $1994 ; 24(1): 1-3$

11 Aboutanos MB, Baker SP. Wartime civilian injuries: epidemiology and intervention strategies. J Trauma 1997;43:719-26.

12 Weinberg J, Simmonds S. Public health, epidemiology and war. Soc Sci Med 1995;40:1663-9.

13 Grossman D. On killing: the psychological cost of learning to kill in war and society. Boston: Little, Brown, 1995.

14 Coupland RM, Samnegaard HO. Effect of type and transfer of conventional weapons on civilian injuries: retrospective analysis of prospective data from Red Cross hospitals. BMJ 1999;319:410-2.

(Accepted 30 June 1999)

\title{
Incidence of weapon injuries not related to interfactional combat in Afghanistan in 1996: prospective cohort study
}

\author{
Markus Michael, David R Meddings, Salah Ramez, Juan Luis Gutiérrez-Fisac
}

\begin{abstract}
Objective To examine the descriptive epidemiology of weapon injuries not directly attributable to combat during armed conflict.

Design Prospective cohort study.

Setting Nangarhar region of Afghanistan, which experienced effective peace, intense fighting, and then peace over six months in 1996.
\end{abstract}

Subjects 608 people admitted to Jalalabad hospital because of weapon injuries.

Main outcome measures Estimated incidence of injuries from combat or otherwise (non-combat injury) before, during, and after the fall of Kabul. Results Incidence of non-combat injury was initially 65 per 100 000. During the intense military campaign for Kabul the incidence declined dramatically, and then differentially increased dependent on injury subcategory - that is, whether injuries were accidental or intentional and whether they were inflicted by firearms or fragmenting munitions. Non-combat injuries accounted for $51 \%$ of weapon injuries observed over the study period. Civilians were more likely to have non-combat injuries than combat injuries.

Conclusions Weapon injuries that are not attributable to combat are common. Social changes accompanying conflict and widespread availability of weapons may be predictive of use of weapons that persists independently of conflict.

\section{Introduction}

Television images of children clutching kalashnikov rifles underscore the fact that in many regions weapons designed for use by trained armed forces are no longer in military hands. ${ }^{12}$ This has been argued to contribute to social violence more generally. ${ }^{34}$
In 1993 the International Committee of the Red Cross began supporting the surgical activities of Jalalabad hospital, 120 kilometres east of Kabul in the Nangarhar region of Afghanistan. Under control of a single authority, this region had not experienced interfactional combat since 1992. On 10 September 1996 the Taliban faction overran Jalalabad without bloodshed and launched its final offensive on Kabul, which fell on 26 September. We examined weapon injuries over six months, before, during, and after the battle for Kabul.

\section{Patients and methods}

From 1 June 1996 to 30 November 1996 all people admitted to Jalalabad hospital with weapon injuries were given a structured interview eliciting demographic information and circumstances surrounding injury. Since Jalalabad hospital was the sole surgical facility in the region, we believe our study includes almost all people injured by weapons in Nangarhar who survived to reach hospital.

The category civilian included all women and girls, boys (aged under 16), and men aged 50 and older. Mine injuries were not included because of the passive way in which they inflict injury. Injuries were classed as combat injuries if they had been sustained during interfactional combat. All other injuries were classed as non-combat injuries and further categorised into accidents, violence, or tribal fighting. Classification of injury was assigned by one of us (MM) on the rare occasions that it was ambiguous.

We calculated the incidence of weapon injury for the whole study and before, during, and after the battle for Kabul. These rates were calculated for an estimated regional population at the mid-point of the study period on the basis of data provided by the United Nations High Commissioner for Refugees.
Editorial by Smith Health Operations Division, International Committee of the Red Cross, 19 avenue de la Paix, 1202 Geneva, Switzerland

Markus Michael health and relief coordinator, Asia and Latin America desk

Unit of the Chief

Medical Officer,

International

Committee of the

Red Cross

David R Meddings

epidemiologist

International

Committee of the Red Cross,

Peshawar, Pakistan

Salah Ramez

surgeon

Department of

Preventive Medicine and Public Health,

Autonomous

University of

Madrid, Arzobispo

Morcillo s/n, 28029

Madrid, Spain

Juan Luis

Gutiérrez-Fisac

associate professor

Correspondence to: Dr Meddings

dmeddings@icrc.org

BMJ 1999;319:415-7 